\title{
Alternative education sites and marginalised young people: 'I wish there were more schools like this one'
}

Glenda McGregor, Griffith University, Australia

Martin Mills, The University of Queensland, Australia

Key words: alternative schooling, marginalised youth, socially just schooling

\begin{abstract}
This paper reports on research conducted in alternative schools/flexible learning centres ${ }^{1}$ designed to support young people marginalised from mainstream schooling in Australia. Many of the young people attending these centres had left school due to difficult personal circumstances and/or significant conflicts with schooling authorities. We argue that the ways in which these schools construct their learning environments, teaching programs and pedagogical relationships are conducive to encouraging such young people to re-engage with educational processes and thus should be supported as viable alternatives within schooling sectors. Moreover, we contend that data gathered from these sites should be used to inform many of the practices within mainstream schools that currently contribute to the marginalisation of certain categories of youth.
\end{abstract}

\section{Introduction}

This paper is concerned with the ways in which 'alternative' schools meet the needs of young people disengaged from the mainstream schooling sector. While the concept of alternative education has a long history located within a progressive tradition in education (Dewey 1966), the term has become a slippery one and is currently used to denote a multitude of practices and sites (te Riele 2007). It is used, for instance, to describe schools located within the democratic schooling movement and to describe behaviour management units designed to modify students' (mis)behaviours so that they are better suited to mainstream schools (te Riele 2006; Thomson and Russell 2009). This paper is concerned with those alternative schools that are non-fee paying and that seek to cater to the needs of young people who are unlikely to return to the mainstream sector for a variety of reasons. Such schools contrast with various systemic schools set up to manage young people suspended and expelled from their former schools which have as their purpose 'disciplining' the young person into a 'normal' student. Thus, the focus of this research was on schools that were not so much concerned with changing the student, but instead focused on changing the kinds of teaching and learning that young people engage in. Such schools are an important feature of the educational landscape in many countries (see for example, Ross and Gray 2005). However, whilst these forms of alternative schools meet the needs of some of the most marginalised young people in society and some of those who have had a traumatic relationship with mainstream schooling, there are also other young people in mainstream schools who are disengaged from the learning process but who simply endure their situations until they graduate. It will be suggested here that there is

\footnotetext{
${ }^{1}$ There was debate amongst participants as to the preferred term 'school' or 'centre'. For purposes of this paper we have chosen to refer to these sites as alternative schools in order to foreground viability as equal pathways of choice within current educational offerings.
} 
much that mainstream schools can learn from alternative approaches to teaching so as to provide an education that is more inclusive of a diverse range of students.

There are multiple reasons why some students disengage from mainstream schooling (Mosen-Lowe, Vidovich and Chapman 2009). These include a schooling rigidity that does not recognise the complex lives led by many young people; authoritarian structures within schools, and often, to these students, irrelevant and meaningless curricula and uncongenial pedagogical practices. This disengagement can have serious consequences for young people who already come from some of the most marginalised sectors of society (Savelsberg and Martin-Giles 2008). In this paper we draw on data collected from a diverse group of alternative schools in the Australian State of Queensland to identify some of the practices that have engaged marginalised young people. Within these schools, the large numbers of students who, despite having rejected mainstream schooling, were prepared to make significant efforts to attend their 'alternative' school was striking. The demonstrated commitment by students to attending these schools led us to conclude, as one participant in the study indicated, that 'there needs to be more schools like these'. This paper proceeds through three main sections. We begin by reviewing the literature on early school leaving, and then present an overview of our research project and research findings followed by our conclusions.

\section{Factors influencing early school leaving}

Early school leaving may be the result of highly individualised circumstances, but research indicates that it is usually the consequence of a complex mix of factors (Taylor 2009; Mosen-Lowe, Vidovich and Chapman 2009; Savelsberg and Martin-Giles 2008; White and Wyn 2008; te Riele 2006; Smyth 2004; Smyth and Hattam 2005). Key influences are social and economic factors (such as socio-economic status SES; family relationships; gender; language and cultural barriers; Indigenous background; poor achievement; the desire/pressure to earn money), and a host of school related issues (such as school policies, pedagogical practices and teacher/student relationships).

\section{Social and economic factors}

The current overall Year $12^{2}$ attainment rate in Australia is 74\% (Australian Govt. FactSheet 2009). A large proportion of the $26 \%$ of students who do not 'make it' are identified as low academic achievers, boys, and Indigenous (Taylor 2009). However, such categories are misleading. The dimensions of social exclusion comprise an intricate web of interdependent features often founded upon poverty. As indicated by the former Australian Federal Minister for Schools and Deputy Prime Minister (now Prime Minister), currently only 59\% of students from low SES backgrounds in Australia finish Year 12 (Gillard 2009). Research consistently supports the link between non-completion and low SES (White and Wyn 2008; Savelsberg and Martin-Giles 2008; Ross and Gray 2005; Lamb et al. 2004). Moreover, data provided by the Organisation of Economic and Cooperative Development (OECD) indicate that the relationship between socio-economic background and educational outcomes is stronger in Australia than in many other comparable countries (OECD 2007). Within the low SES segment of the population, Indigenous students struggle with the multiple challenges posed by geolocation, colonization, generational

\footnotetext{
${ }^{2}$ The final year of schooling in Australia
} 
marginalization and cultural and language barriers ('Closing the gap' 2009). Many of these issues are shared by refugee and newly arrived immigrant youth. For marginalized young males within all these social categories, the risk of dropping out of school is even greater (Lingard, Martino and Mills 2009). However, whilst it is true that, on the whole, completion rates are generally higher for females, research shows that gender continues to be a factor for vulnerable young women from low SES, particularly when coupled with teenage pregnancy (Connell 2009).

Families in economic difficulty may also have higher levels of residential and school mobility that impact upon the ability of students to maintain continuity in their academic studies and establish strong networks of support amongst peers. Combined with increased responsibilities in respect to siblings and early job seeking, such contexts increase the risk of non-completion of schooling (Gray and Beresford 2002; White and Wyn 2008). Many researchers identify a range of socio-cultural disadvantages experienced by some young people right from their first year (Alexander, Entwisle and Kabbani 2008). A lack of expertise in a whole range of taken-for-granted middle class socio-cultural situations, or 'cultural capital' (Bourdieu 1984), creates an achievement gap that widens over time unless there is sensitive and sustained intervention by the school (Apple and Buras 2006). If this gap remains and grows the consequences include low achievement, low self esteem and eventually disengagement from learning (Teese and Polesel 2003) often provoking resistant behaviours in the classroom and school. These challenging behaviours position such students for cycles of conflict with schooling authorities often leading to absenteeism, suspension, expulsion or 'dropping out'.

A generation ago, many young people, particularly from low-SES backgrounds, routinely left school early to seek employment, however, rapid socio-cultural change and global economic restructurings have made this pathway less viable and fraught with individualized 'risks'. Contemporary sociological research suggests that society is now characterized by new, unequally distributed, risks and challenges that require individual responses:

Like wealth, risks adhere to the class pattern, only inversely: wealth accumulates at the top, risks at the bottom. To that extent, risks seem to strengthen, not abolish, the class society. Poverty attracts an unfortunate abundance of risks. By contrast, the wealthy (in income, power or education) can purchase safety and freedom from risk. (Beck 1992, 35).

For those young people who are most vulnerable to non-completion, this wider social context adds to their dilemmas. In an era of neoliberal national educational competitiveness (Apple 2006; Ball 2006) they become 'the problem' for failing to negotiate the hazards of this so-called 'risk society' that demands increasing levels of social, emotional and educational capital to succeed. Schools are positioned to play a vital role in helping students to develop such competencies, but there must be greater attention paid to the broader socio-economic context and its inherent inequalities. In recent years, government discourses have re-cast the terminology of this problem. Social justice has been replaced by equity. Equality of opportunity has overtaken notions of affirmative action with deficit labels attached to those young people who 'fail' to seize it. An 'equitable' approach ignores the social reality that children start school from very unequal positions and thus perpetuates class based inequality. According to Taylor and Singh (2005): 
(While) ... shifts in language are not in themselves enough to effect more fundamental changes in approach which are necessary in implementing major educational reforms ... they may easily result in ... issues slipping off agendas ...(and) ... the particular needs of these groups ... (being) ... glossed over, and economic and cultural differences become recontextualised as individual differences (11).

Once they enrol, some young people struggle to connect with the culture of the school. Their unique background combinations of gendered influences, family practices and support systems, language development, emotional and social capital and class positioning all contribute to the shaping of a young person's attitude towards schooling. Empathy and support systems from the school are therefore vitally necessary to the academic success and social well-being of many students. The next section looks more closely at the systemic and school based issues that may contribute to early school leaving.

\section{Schooling factors}

School cultures are connected to processes of departmental policy and accountability that impact on teachers' options in terms of behaviour management and negotiations with students. As young people move through primary into secondary schooling, and in particular into the senior phase, the rules pertaining to curriculum content and assessment become increasingly inflexible. Credentialing and rankordering of students demand regimes of comparability and uniformity of assessment that take little account of the life circumstances of marginalised youth. Whilst there are opportunities for students to apply for 'special consideration', the reasons are usually limited to fairly specific emergent medical and family circumstances that do not recognise the accumulative nature of the debilitating effects of poverty, family break-down or conflict along with the general uncertainty of life circumstances that may arise from these and other factors of social marginalization. Additionally, vulnerable students may not have the confidence and/or skills to use systemic avenues of appeal, particularly if they have a history of conflict with school authorities. The 'system' presents itself as an unfriendly maze of rules and paperwork that is overwhelming to students who are often already disengaged and/or alienated from schooling processes.

Rules that apply to uniforms, self-presentation, social interactions and assumptions of unquestioning obedience to adult power position certain students for on-going systemic conflict. The young people who live in unstable and/or unsupportive/neglectful environments will find it difficult to comply with many of the cultural expectations of mainstream, middle class schools. Others may struggle with school rules for a variety of reasons that range from behaviours associated from special needs to sophisticated personal philosophies of individual freedom (McGregor 2009). However, regardless of the reasons, young people who are suspended or excluded from school due to behavioural issues have a right to an education. Research carried out in the UK (Thomson and Russell 2009) argues that school cultures, curriculum and practices are all implicated in student disengagement and behaviour and therefore educational authorities have a duty to ensure that all children have access to a high quality education. Teachers provide a bridge between young people and education systems. Classrooms are the educational interface at which connection or disconnection occurs for students. Thus, the relationships and pedagogical practices within these spaces are fundamental to engaging and retaining the interest and trust of students (Smyth and Hattam 2005; McFadden and Munns 2002). 
Founded on notions of developmental psychology, deficit models of youth frame many responses to noncompletion of schooling and educational failure is often attributed to faults within the individual child (Ball 2004). In an age of increasing individualisation of risk, the response has been to situate the blame within the student. Quinn et al. (2006) argue strongly against this notion:

When a child fails to learn and grow, the fault lies not solely with the child but instead lies mainly with the system and the adults responsible for it (11).

Te Riele (2007) also makes the point that rather than targeting so called 'at risk' youth - schools need to change from a focus on uniformity to a focus on diversity.

Official labels such as 'at-risk' and 'disengaged' youth tend to individualise the issue of early school leaving, drawing attention away from the contextual issues of teacher-student relationships, curriculum content and teaching strategies. Many classrooms continue to be formal, hierarchical and structured around the accepted power of the teacher to control the content, pace and direction of lessons (McFadden \& Munns, 2002). Whilst most students will endure, though not necessarily enjoy, this situation, for students whose lives have little resonance with the explicit and 'hidden' curriculum of their classroom and who lack the cultural capital necessary to avoid confrontation, disengagement and disaffection with learning are likely, and often understandable, consequences. Gable et al. (2006) identify a mis-match between the structure of schools and marginalised segments of the population and a failure on the part of schools to address diversity and a possible 'school readiness gap'. The lack of space for students to insert their own experiences alienates them from the shared culture of the classroom. Traditional teaching practices often fail to take into account what students bring to the pedagogical relationship and reasons why they might comply with or resist school practices. Subsequent power struggles between such students and their teachers may lead to increasing levels of coercion and punishments (Gable et al. 2006) that erode positive elements of teaching and learning.

Within all relationships, emotional issues must be considered. Schools are often the sites where students give vent to emotions generated elsewhere - home, peer, social etc (McFadden and Munns 2002). A recent investigation into schooling responses to youth crime (Reid 2009) highlights the importance of the role played by teachers in investing emotional capital in their students. Earlier research confirms this perspective, situating emotional capital at the very heart of education. According to Harding and Pribram (2004), 'emotions ... (have a place) ... in the production of knowledge, culture, individual and collective identities, and power relations' (864). Emotions experienced by students such as despair, resentment and low self-esteem lead to early school leaving, and, according to Gable, Bullock and Evans (2006), 60\% of early leavers suffer various emotional problems. On the other hand, the emotions expressed by school authorities often demonstrate a desire to simply rid themselves of the problem. Schools often want such students removed from the school as illustrated in this comment by a school principal interviewed by Skiba and Peterson (2000):

You don't get it ... we don't want to understand these kids; we want to get them out (340).

Whilst such a comment is not representative of all principals in all schools, it points to the complexity and emotionally charged nature of the problem (see also Morrison and Skiba 2001). Approaches that attempt to 'fix' the student in isolation from such contextual influences will continue to falter because they look at 
only one half of the problem. Reid (2009) suggests that schools can do much more to harness emotion as 'a socio-cultural product rather than something that resides in the individual psychological make-up of a student' (2). Reid further argues that a lack of hope can lead to disengagement and cites instances of teachers 'investing emotional capital ... (of engaging) in a form of emotional labour that attempts to induce appropriate behaviour through investing more emotion in a relationship developed through trust' (11). She concludes with a call for schools to facilitate 'networks of trust'.

In summary, it is possible to identify a number of themes from the literature about early school leaving and the role played by mainstream educational sites and providers. Whilst they cannot 'fix' the broader socio-economic and cultural influences on the lives of their students, they are positioned to shape learning: learning environments; learning programs and the learning that comes from effective teaching. In this paper we argue that recent research into five diverse flexi schools/centres in South East Queensland, attests to the importance of these three factors (environment, programs and teaching) in retaining, engaging and motivating students who have 'dropped out' or who have been 'pushed out' of mainstream schools. The next section explains the nature of the research supporting this paper and reviews data from students and workers at the five alternative schools visited.

\section{The research: investigating flexible alternatives to mainstream schooling}

Across South East Queensland, where this research was located, there is a variety of alternative education centres and schools (see for example, Connor 2006 ). However, the number of sites is difficult to determine for, as many of the young people indicated to us, there is little public information on the existence of these sites. This is not uncommon for such learning centres, as Thomson and Russell (2009) discovered in the UK (see also Australian Industry Group (AIG) Dusseldorp Skills Forum (DSF) 2007). Supporting this research was an advisory body consisting of members representing various youth organisations, educational bodies and charity groups in Queensland. Through the knowledge base of this group a list of about 15 sites was generated. From this list five sites were chosen to represent diverse forms of alternative schooling within South East Queensland. This diversity related to the age range of young people catered for, the curricula offered, and funding sources and size of student population (see Table 1). Thus, for instance, only one school funded by Queensland's state department of education and only once site with a purely vocational curriculum were included. Some of the sites though were quite unique, for example Fernvale (see below). Some of the excluded sites included Technical and Further Education (TAFE) centres and sites located on mainstream school grounds (for some examples of these see Connor 2006) as the intent of this research was to explore the practices in sites deemed nonmainstream. For the same reason, we also ruled out those centres that were behavioural units established on the premise that students needed to be 'fixed' to fit the mainstream.

The sites included were: Fernvale Education Centre, a church funded high school for girls who were experiencing serious family and other personal problems; Woodlands Flexi School, a regional flexible high school that was overseen by a local high school and supported by community organisations; Cave Street Flexi School a very small school located under an urban house with one teacher and a social worker, catering to young people up to the age of 16, and which was funded from small pockets of money from a variety of local high schools; Victoria Meadows Flexi School, an inner city school enrolling young people from 15 to 25 years, co-funded by a Christian church and a city council; and the Garage a learning 
centre that was primarily concerned with providing students aged 13-17 with work experience, mainly in relation to motor mechanics, and was funded by a large community organisation. The visits to each of these sites lasted for approximately one week and involved observations and document collection and interviews (focus and individual) with young people, workers from the sites, and in some instances parents and former students. Interviews lasted from 30 to 90 minutes and were electronically recorded. In all, we interviewed one parent, 26 teachers and workers, three former students and 41 current students from across the five alternative schooling sites. Pseudonyms are used for all sites and interviewees.

\section{INSERT TABLE 1}

\section{The students}

Data from the study show a diversity of student population in terms of their personal circumstances and reasons for attending alternative schools. The students from Fernvale were girls and young women who had experienced a wide range of difficult life circumstances. Some were mothers, or pregnant, some had experienced violence or sexual assault in the home and some were homeless. There was a very high proportion of Indigenous students at the school. There was an even gender balance of students at Woodlands, who in the main came from rural backgrounds, were predominantly from low income homes. Cave Street students tended to be young white working class boys; there were five girls in the school population. Students from Victoria Meadows came from a range of ethnic backgrounds, although white Australian students were in the majority, and many were living independently. The school also catered to young mothers. The Garage student cohort was primarily male with a large Pacific Islander population. All the students at this centre came from low income families.

Evidence from our investigations thus clearly supports the research that points to broader socio-economic factors being major contributors to young people's disengagement from mainstream schooling. For instance, we came across students who were, or who had been, highly transient, and/or homeless. For example, Tom from Woodlands Flexi School, stated:

I moved out about two months ago ... for about a month and then I moved back and I'm back with my mum now....

And a worker, Angela, from Victoria Meadows Flexi School made the following observation:

We've got a couple of kids who have like very tentative housing arrangements - one kid that lost his house a few weeks ago was in a share house situation and then that fell apart then ... he would have been homeless for a little bit and now he's kind of organised a meeting with someone's family. And another girl she- was homeless for quite a while but now she's living with her boyfriend's mum and her boyfriend.

Our data also show that some students were returning to education after a long absence. Consequently, the age range of students sampled was quite broad - ranging from early teens through to early 20 s with varying levels of support. It was also common for early school leavers to have experienced considerable 
family mobility, a factor that contributes to the social, emotional and academic disengagement from school. According to three young interviewees:

Glen (The Garage): Well I've been to nine different schools, so yeah ...

Elizabeth (Victoria Meadows Flexi School): I think I've been to eleven primary schools and by the time I was in Year Seven I went to three different schools in the (same) year.

Along with such instability, a number of young people found that due to family circumstances they had to begin work at an early age and this inevitably impacted upon their schooling. The following student found himself alone and trying to balance school attendance requirements as well as working to survive without family support:

Malcolm (Victoria Meadows Flexi School): I left school about three months before I finished Year Twelve. I got expelled because I had a pretty big personal conflict with my old school principal at Bielby Creek. Pretty much he told me that I was useless ... I was working and he was like, 'you're not attending school' and I was working my arse off. I didn't have no parents supporting me because my parents are deceased and he didn't want to believe that they were deceased. I pretty much had to take in their death certificates to school to prove to him that they weren't alive ... He would just pretty much, like I was just a dropkick of the community because I had no parents..

We also found one student, a young man of 20 who was coping with fatherhood with the help of his family:

Patrick (The Garage): Oh yeah, my son lives with me - me and the mother are still together but she works in Cairns (approximately 1800kms away)...

For many more girls, however, becoming pregnant whilst still at school is still a major obstacle to continuing their education:

Claire (Fernvale Education Centre): I was pregnant and wasn't allowed to return to (my school) .... because I was going into Grade Twelve and they said that I'd start a fad for the younger children to all come to school pregnant! ...

While the backgrounds of the students were diverse we were able to identify various commonalities in their present circumstances. These included resolute life ambitions and a strong work ethic as many of the students put a great deal of effort into attending school. Some juggled work and/or caring responsibilities while others travelled significant distances to maintain their connection to learning.

During an interview with one young student it emerged that her daily trip to the alternative school took 90 minutes (when the buses were on time). On the way to school she passed several other mainstream schools, the closest of which was just a five minute walk from her home. Clearly there were highly motivating factors making her put up with a long trip on unreliable public transport every day to get to her chosen school. However, data from this project reveal that hers was not an isolated case. The young 
people interviewed for this project frequently commented upon their renewed enthusiasm for learning and their willingness to travel long distances to their current schools.

Additionally, despite the diversity of background of the students and the differences amongst the research sites, we found many commonalities among the factors that drew young people to the alternative education centres. These included the learning programs, the environment, teaching strategies and relationships. The following sub-section reviews our data around each of these elements.

\section{The learning programs}

There were opportunities for young people across the sites to undertake traditional subjects and curricula, for instance at Woodlands Flexi School, students could obtain a matriculation certificate, the Queensland Certificate of Education, through undertaking regular Queensland curricula. There was also a focus on learning work skills; for example, Woodlands ran a 'work on trial' program providing opportunities to obtain experiences in local workplaces and also combined regular subjects with a program focused on obtaining Vocational Certificates in Retail and Construction. The opportunity to obtain vocational qualifications was common across a number of the sites. At the Garage, in addition to opportunities to undertake regular curricula - taken up be very few young people - there was a program which enabled young people to work towards an automotive certificate. Similarly at Victoria Meadows Flexi School, in addition to standard curricula, students had the opportunity to obtain work related qualifications. Fernvale Education Centre ran a standard curriculum. However, there was a strong Indigenous focus within this curriculum due to the large number of Indigenous girls attending the school. Because of its size, Cave Street Flexi School was only able to offer a limited program. Its focus was on helping students to complete basic literacy and numeracy requirements that would facilitate student access to senior secondary education and trade certificates.

Learning programs within the schools thus varied depending on their context and clientele. Common across the research sites was the endeavour to cater to the needs of the students who chose that particular place. Some were classed as 'schools' whilst others as 'centres' and 'work sites'. Accordingly, there was a diversity of offerings and students had to seek out the site that would give them the best chance of fulfilling their goals. Students frequently commented on the need for greater access to such facilities:

Mary (Victoria Meadows Flexi School): If they created more of these small schools - like say in just main suburban areas - then I reckon it would have a huge popular demand and kids would be saved from going down the wrong track.

Most students talked of wanting to finish school - to complete years 11 and 12, some wanting to pursue tertiary studies. One of the sites we visited had developed a relationship with a local university:

Renee (Woodlands Flexi School): The good thing is that in Year 12, if you've been through year 11 and 12 you can do the Tertiary Preparation Program which will get you into uni ... Even if I move out of home later on I can still have that option ...

Other sites focused more upon Year 10 courses, (e.g. in woodworking, automotive engineering, literacy and numeracy), and vocational education (e.g. certificate courses linked to trade traineeships or apprenticeships). Work experience was a common feature of many programs. Students appreciated the 
more hands-on approach. There were also opportunities to do short courses to help with employment, e.g. barista training, first aid courses and photography. Programs offered at these alternative schools also included courses and activities that contributed to the personal development of their students. Art and music, music production, animation, photography, field trips, community service and a great variety of life skills (e.g. cooking, sport, personal fitness) were offered in varying degrees across the research sites:

Sharon (student, Victoria Meadows Flexi School): The music program has been consistently amazing and wonderful. They've had the right teachers at the right times ... I think the big difference is the fact that they've got their basic Maths and English classes, but they have this huge variety of art subjects.

Whilst the academic offerings were core business for the students, our data show that there were other factors at the research sites that facilitated the engagement of these young people. The sites provided a schooling experience that was positive enough to make these young people want to reconnect to learning and allow them to dream different futures for themselves At these centres, the curricula were delivered within flexible and inclusive environments founded upon supportiveness and respect. . These attributes also underpinned the teacher/student relationships present in these sites. Because the conduct of human relationships shapes environments, the following section makes reference to their impact, particularly in respect to creating communities. However, so significant are these relationships to the success of the educational sites that they will be further elaborated upon following the discussion of environments, in terms of the way they shaped pedagogy.

\section{The environment}

The environments at the various centres all tended to be far more relaxed than those found in traditional mainstream schools. Issues in respect to attendance, uniforms, assessment deadlines and behaviour were handled with greater flexibility and an on-going staff-student dialogue. In terms of attendance and assessment deadlines, for example, Simon from Woodlands Flexi School stated:

'Cause you get flexible hours here and stuff, if you're working then you can pick the day you need to do subjects on ... I only do two subjects here, I'm only doing English and Maths at the moment, I'm hopefully going to be doing full-time now.

A core aspect of all of the centres, many of which had waiting lists, was that attendance was voluntary. The centres did not appear to want to be sites which young people were compelled to attend. For instance, a social worker, Angela, from Victoria Meadows Flexi School indicated:

We work from a framework ... informed by adult education models so that ... anyone who comes here has to want to come here. We can't operate with young people who have to come, who are mandated to come and who don't want to; it's okay if they're mandated and they want to, but it has to be that personal drive to come. So that's how we operate we say, 'Well, aren't you here because you want to be here and didn't you say that you wanted to do this?'

Students also identified a sense of common purpose and community as significant elements of their alternative schooling environment: 
Molly (Victoria Meadows Flexi School): I think how they do the community group meetings (well) ... bringing everyone together and sorting out conflicts and everyone having their say. And these little meetings is a really good thing ... because it lowers the chances of anyone having any sort of fights or arguments so everyone has their own opinion - so it brings people together as a one community.

For the teachers and workers at these schools, building a sense of community was fundamental to ensuring that the young people remained in the educational programs offered at each site. It was often suggested that this community was not something that was readily available in mainstream schools. For instance, George from Victoria Meadows Flexi School shared this view about community:

I think the other strength that this place offers is a place where difference is accepted, where alternative viewpoints are accepted, alternative lifestyles are accepted in a safe and respectful environment where your ability to succeed in academic endeavours isn't the be all and end all of you as a person.

Similar views were articulated by Paul at The Garage:

I think generally speaking it is a place where they can get a feeling of belonging, where they can get a feeling that it's a place ... to go that doesn't have that strict classroom-type feel about it. That they do have certain freedoms ... (but) I call it education by stealth. The education's not spoon fed or forced down their throat. A lot of the education in literacy and numeracy and so forth is delivered out on the floor. If they've got to prepare a job for instance, I mean they're learning literacy. If they're working out the cost of a repair to a vehicle they're learning sums numeracy.

As indicated by Paul here, positive relationships with the young people helped to ensure that they engaged with the school's curriculum. Juliet, the teacher from Cave Street Flexi School, likewise emphasised the importance of relationships:

Well my number one thing that I've learnt here in order to gain their cooperation because many of them ... are a bit anti 'teacher' - is, relationships first, number one... So establishing relationships - they respond to that very well. Some of them - it takes a while because they've lost trust, not only in maybe some teachers they've had, but also adults in general - home stuff and whatever. So once they know they're safe, it's consistency of treatment, so no screaming, no shouting from myself, or from the youth workers.

Caring about the young people individually was also seen as a strength of Fernvale Education Centre. When asked what the school offered the girls, a teacher, Penny stated:

It gives them a face ... it's because of the positive regard policy that we have here, even when you walk in you know, 'Hello, how are you, it's great to see you here. I haven't seen you for a few days it's great that you're back'. (Administrators) stress that to us all the time and, you know, really it's common courtesy - a smile. You know - 'How are you?' and reconnecting with the girls if they've told you something about one of their hobbies- 'Oh how did you go on the weekend?' 
To some extent respect for the students means forgetting or ignoring their past, seeing this educational journey as some of the workers referred to it, as a new start. Emma, the head teacher at Woodlands Flexi School stated that:

Now we do get students with a rap sheet, you know ten pages long of behaviour issues ... and I'll say, I interview every student and I'll say, 'look yep, yeah this is the past, okay, yeah all right I really want to talk about your future and I don't want to see this here' and then we sort of put that to the side and - 'Right, what do you want, why do you want to be here?'

Accepting students for who they are was a key feature of the philosophy at Cave Street Flexi School:

Juliet (teacher): They like the attention, individual attention. They have some plans for themselves for the future. They like each other. They have fun when they come here. They have the right to smoke - some of them are quite addicted and can't go because the classes are two hours in length. Now I think that's really quite challenging to them. I mean, we do get up occasionally and go for a walk just around the classroom or outside - I mean, it's just really a car park! We negotiate smoke breaks.

One student, young parent, for instance, found that her alternative school accepted the fact she was a young mother, saying:

Maxine (Victoria Meadows Flexi School): I can still have my education, my son can come and it's like, I don't know, it's so much different to a school like - you have a really good relationship and bond with the teachers and other students.

Other students noted a variety of significant support systems in place at these schools:

Claire (Fernvale Education Centre): If you're wanting to get away from your family problems you just come to school, you know you can talk to one of the teachers or one of the youth workers and just nut it out...

At Woodlands Flexi School, it was suggested that treating the sites, like the ones described here, as places to send young people as punishment for not appearing to fit in with mainstream schools would be counterproductive. For instance, Julia, a senior teacher, stated:

You don't want it to be something where kids feel embarrassed to go to ... you must be dumb or naughty. You want it to be an alternative education where you can come, choose the program that you need to do to get to your goal - that's the key...We're not a dumping ground. We're not here about punishment. We're about you making the choice.

The respect that students felt was also a big factor, both between staff and students and amongst students as well:

Molly (Victoria Meadows Flexi School): ... Respect... it's one our four Rs. It's not a place where you can relax and be cool and do drugs and not do your schoolwork because that's not what we're about. 
The positive focus of schools was also important, both in terms of young people feeling 'celebrated' (not just accepted), and being able to relax in a positive environment:

Claire (Fernvale Education Centre): I was pregnant and everyone (here) was going, 'Oh look you're pregnant, look at that little bump!' Whereas at (previous school) it was like 'Hide it', you know, 'We don't want to see it!'

Renee (Woodlands Flexi School): Oh yeah everyone's pretty laidback ... and we all talk to each other, and the good thing is there's no actual real bullying here.

Thus, the environments of these alternative schooling sites provided compassionate and sensitive contexts for the delivery of their curricula. Supportiveness, care and respect were key elements of the communities that had developed within these schools and were fundamental to the relationships among all (staff and students) who attended. We now turn to focus more specifically upon the impact such relationships had upon the academic engagement and success of the students. According to both staff and the young people they taught, it was the pedagogical relationships fostered within these sites that were key factors in their success.

\section{The teaching relationships}

The relationships that were part of the broader environment in the research schools were reflected in the teaching/learning relationships within the sites. The environment, that is the structures, procedures and pastoral care within each school, clearly shaped the ways in which the teachers/workers at the various sites engaged on a person level with the young people in the delivery of the curricula. These relationships were identified by young people and workers alike as being central to the young people's on-going engagement in the learning processes at the sites:

\section{What do you think people do here that helps you to learn that didn't happen at other schools?}

Nick (student from Cave Street Flexi School): They're a lot more personal and they sit there and help you out and they have time to go round and check on different people. And everyone's at a different level so it's not like you have to keep up with people. You go at your own pace...

The issue of teacher/student relationships and the teaching strategies that flowed from that was a dominant theme within the data from our study. Students frequently used adjectives such as 'caring, small, community, family, respectful, equal, supportive, non-judgemental, mutual responsibility' when discussing their school. The following comments are just a small selection from the many positive endorsements from students:

Christine (Fernvale Education Centre): Extremely different, extremely different (from previous school) because ... you can go to anyone when you have a problem. It feels like a big family rather than just, you know, a thousand students all clumped together.

Joan (Fernvale Education Centre): They don't judge you by what is happening in your home life. They'll support you all the way but they won't tell you, 'Absolutely not, you can't come here any 
more' - they say, 'If you're having a hard time you can just come in'. It feels more like they're trying to help you more than any other school. Like they want you to learn...

\section{What are the main ways that this is different from mainstream schools?}

Oscar (Victoria Meadows Flexi School): It's just a lot more relaxed. I mean you've got your assessments and your assignments to do but it's not like if you don't do them you're gonna fail completely - no, you can come back and you can do it again. I mean you've got time to do things.

Across all five alternative schools, workers and teachers allowed and encouraged students to call them by their first name. This practice definitely seemed to contribute to a breaking down of teacher/student barriers as shown here:

Mary (Victoria Meadows Flexi School): We get called by our first name and we call them by their first name so it's like an equal ground and it makes it so much more easier to connect and be more friendly with them than calling them Mrs or Mr.

Many students commented on the effectiveness of teaching strategies that they described as 'real life', 'hands on', 'connected' and 'conversational'. Teachers gave them sufficient time and assistance to complete their work:

Mark (Woodlands Flexi School): It's more like life skills kind of thing as well - it's not sit down and do it in a book, read from a book kind of thing. It's teaching you how to kind of live I think...

Joan (Fernvale Education Centre): They'll come (teachers/workers) and talk to you and check up on how you're doing. Like if you don't understand something they'll come and help you and it's just, they're more supportive.

Glen (The Garage): It's more relaxed. You get more time if you want more breaks or something. You just work at your own pace ...

David (Cave Street Flexi School): Everyone was just leaving me out, helping everyone else because I was one of the dumbest people in the class... I feel a lot better about myself now (with the teachers helping us) ... Learnt more here than I did at normal school anyway - in the two months that I've been here ...

Such comments are not meant to suggest that there are not tensions and conflicts at these centres. However, it is the flexible ways in which they are dealt with that make a difference:

Julia (senior teacher in charge Woodlands Flexi School): So really we don't have a behaviour management problem - if kids misbehave here I'll always talk to them - what's going on today? Did something happen at home? - And generally, ninety-nine percent of the time they've had a bad day, had a fight with mum before they came or something happened and we will just tell them, look go home. That's our behaviour management policy - go (and) when you're ready to come back and learn, come back, and we have a re-entry interview - so they come back to school 
and we just discuss it before they go back into class. So we don't really let situations blow up to the point where it becomes conflict. We just say, 'Look you're not ready today, go home'.

Supporting arguments made in a lot of the academic literature about early school leaving, the evidence derived from this study shows that for young people who are most at risk of dropping out, it is the emotional labour of the teachers and workers that often makes a difference. Moreover, the pedagogy that flows from the closer relationships engages and motivates students.

\section{Discussion}

One of the young people in the project made the comment that there needs to be more schools like these. We concur. The schools we visited were providing opportunities for many young people who had been marginalised from the mainstream schooling sector to (re)engage with education in positive ways. Such opportunities are critical to re-engage young people in education and to further their life chances. It is especially important in Australia where the relationship between non-completion and unemployment is stronger than in many other OECD countries (OECD 2007: see also AIG \& DSF 2007). Thus, as the AIG and DSF $(2007,20)$ report It's Crunch Time indicates, providing opportunities for young people disengaged from the education system has to be 'a policy priority'. However, in addition to economic imperatives, we and others (Thomson and Russell 2007; 2009) argue that it is also essential to foreground the entitlement to a high quality education with broad choices for marginalised and disengaged young people. The schools which were the basis of our study provide some indication of how such goals might be realised.

As with other research (for example, Alexander et al. 2008; White and Wyn 2008), our study indicates that the socio-economic factors that shape the life circumstances of young people do have a significant influence on schooling experiences and educational success. What made the schools studied here stand out was the way in which they recognised the difficult social and economic circumstances faced by many young people who were early school leavers. Hence, they provided crèches and social workers and employed Indigenous staff to help their students to find homes and to negotiate with welfare agencies. This recognition of the broader social factors that often contribute to early school leaving meant that many of the students were provided with the conditions that enabled them to attend school.

However, by itself, such practical support, whilst extremely important, would not have been sufficient to keep these young people at school. Attention was also given to creating school structures, curricula and pedagogy that made the schools attractive to the students. Such conditions have been widely recognised as critical for re-engaging young people in education (AIG \& DSF 2007).The structures within these schools acknowledged, for example, that there were often life circumstances that required flexibility of attendance, that recognised many students were addicted to nicotine and required time off the premises to smoke, and that having young people involved in decision making, not having uniforms and being able to call the adults by their first names helped to create an environment where students felt like equal partners in the teacher/learner relationship.

The curricula provided sought to support students obtaining part time work, through short courses such as barista training, whilst also providing students with opportunities to obtain year 12 matriculation, university entry, vocational qualifications and life skills. This 'flexible pathways' approach was a key 
recommendation of a report commissioned by the New South Wales Department of Education and Training (DET) published in 2005. In order to facilitate student engagement in meaningful learning, the report advocated the need to 'provide flexible pathways and enable students to exercise greater control over their own learning' (NSW DET, 2005, 282). Moreover, the report argued for a more holistic approach to education via partnerships of government agencies, industry and community. Such a 'full service' philosophy of education was clearly evident at our research sites. Also fundamental to this philosophy was the supportive web of relationships among staff and students.

Our data show that the pedagogical relationships within each site encouraged student reconnection to learning. Across the various sites, young people suggested that the relationship with workers and teachers was a key factor in their enthusiastic engagement with the curriculum. They also suggested that the quality of this relationship had been compromised in their mainstream schooling experiences. This is perhaps not surprising, as the AIG \& DSF $(2007,23)$ report states: 'Our systems are relatively good at identifying curriculum standards but weak at constructing and supporting the personal and classroom relationships so crucial to productive learning.' For students in the middle years (when the possibility of disengagement is heightened) strong bonds with teachers have been shown to be particularly important (NSW DET 2005). Thus whilst the teachers and other workers at the sites sought to make the curricula relevant or connected to the lifeworlds of the young people, they also worked on developing a positive emotional connection between themselves and the students; they opened up opportunities for students to engage with new knowledges and they valued the diversity of the student body of the school. The relationships developed through these practices can, as the (AIG \& DSF 2007, 35) report suggests, be 'life changing'.

\section{Conclusion}

We would suggest that many of the practices in these schools have a place in mainstream schools and that such practices would be beneficial to all students. We would, however, like to offer one word of caution in advocating for more schools like these. Access to an education that provides students with deep knowledge of disciplines and that encourages students to engage in work of high intellectual quality, is critical for success in further education and to a broadening of life chances. We would be concerned if alternative or flexi schools became sites where students who were deemed to be 'a problem' were 'offloaded' and where a limited 'dead-end' curriculum was offered in a way that constructed such schools as offering a remedial form of education. We would suggest that such schools should be constructed as a genuine alternative that still provide quality curricula and facilitate access to higher and further education beyond the school years. As such they would provide recognition that a one-size-fits-all schooling model often further marginalises those students who already face significant social and economic difficulties in their everyday lives. 


\section{References}

Alexander, K., D. Entwisle and N. Kabbani. 2008. The dropout process in life course perspective: Early risk factors at home and school. Teachers College Record 103, no. 5: $760-822$.

Apple, M. 2006. Educating the 'right' way: Markets, standards, god, and inequality ( $2^{\text {nd }}$ Ed.). New York: Routledge.

Apple, M., and K. Buras, eds. 2006. The subaltern speak: Curriculum, power, and educational struggles. New York: Routledge.

Australian Government FactSheet: Compact with Young Australians: Increasing educational attainment of young people aged 15-24. 2009. Retrieved from http://www.deewr.gov.au/Youth/YouthAttainmentandTransitions/Documents/CompactQAsWeb.pdf on $13 / 5 / 10$

Australian Industry Group and Dusseldorp Skills Forum. 2007. It's Crunch Time: Raising Youth Engagement and Attainment - A Discussion Paper. Retrieved from http://www.aigroup.com.au/portal/binary/com.epicentric.contentmanagement.servlet.ContentDeliveryServl et/LIVE_CONTENT/Publications/Reports/2007/Crunch_Time_Full_August07.pdf on 28/9/10

Ball, S. 2006. Education policy and social class: The selected works of Stephen Ball. London: Routledge: Taylor \& Francis.

Ball, S., ed. 2004. The RoutledgeFalmer reader in sociology of education. London, New York: RoutledgeFalmer.

Beck, U. 1992. Risk society: Towards a new modernity. London: Sage.

Bourdieu, P. 1984. Distinction. London: Routledge.

Closing the Gap on Indigenous Disadvantage: The Challenge for Australia. 2009. Canberra: Commonwealth of Australia.

Connell, R. 2009. Gender. $2^{\text {nd }}$ ed. Cambridge: Polity Press.

Connor, J. 2006. What's mainstream? Conventional and unconventional learning in Logan. Dusseldorp Skills Forum. Retrieved from http://www.dsf.org.au/resources-and-research/184-whats-mainstreamconventional-and-unconventional-learning-in-logan on 23/9/10.

Dewey, J. 1966. Democracy and education. New York: Free Press.

Gable, R., L. Bullock, and W. Evans. 2006. Changing perspectives on alternative schooling for children and adolescents with challenging behavior. Preventing School Failure 51, no. 1: 5-9.

Gillard, J. 2009. Speech. Australian Financial Review - Higher Education Conference - 9 March.

Gray, J. and Q. Beresford. 2002. Aboriginal non-attendance at school: Revisiting the debate. Australian Educational Researcher 29, no. 1: 27-42.

Harding, J. and E. Pribram. 2004. Losing our cool? Following Williams and Grossberg on emotions. Cultural Studies 18, no. 6: 863-883.

Lamb, S., A. Walstab, R. Teese, M.Vickers and R. Rumberger. 2004. Staying on at school: improving student retention in Australia. Centre for Postcompulsory Education and Lifelong Learning: The University of Melbourne.

Lingard, B., W. Martino and M. Mills. 2009. Boys and schooling: beyond structural reform. Hampshire, England; N.Y: Palgrave Macmillan.

McFadden, M., and G. Munns. 2002. Student engagement and the social relations of pedagogy. British Journal of Sociology of Education 23, no. 3: 357-366.

McGregor, G. 2009. Educating for (whose) success? Schooling in an age of neo-liberalism. British Journal of Sociology of Education 30, no. 3: 345 - 358.

Morrison J. and R. Skiba 2001 Predicting violence from school misbehaviour: Promises and perils. Psychology in the Schools 38, no. 2: 173-184.

Mosen-Lowe, L., L. Vidovich and A. Chapman. 2009. Students 'at-risk' policy: competing social and economic discourses. Journal of Education Policy, 24, no. 4: 461-476. 
NSW DET. 2005. Report of the consultation on future directions for public education and training: One size doesn't fit all. Sydney: NSW DET

Organisation of Economic and Cooperative Development. 2007. Education at a glance. OECD.

Quinn, M., J. Poirier, S. Faller, R. Gable and S. Tonelson. 2006. An examination of school climate in effective alternative programs. Preventing School Failure, 51, no. 1: 11-17.

Reid, C. 2009. Schooling responses to youth crime: building emotional capital. International Journal of Inclusive Education 13, no. 6: 1-15.

Ross, S. and J. Gray. 2005. Transitions and re-engagement through second chance education. The Australian Educational Researcher 32, no. 3: 103-140.

Savelsberg, H. and B. Martin-Giles. 2008. Young people on the margins: Australian studies of social exclusion. Journal of Youth Studies, 11, no. 1: 17-31.

Skiba, R. and R. Peterson. 2000. School discipline at a crossroads: From zero tolerance to early response. Exceptional Children 66: 335-347.

Smyth, J. 2004. Social capital and the 'socially just school'. The British Journal of Sociology of Education 25, no. 1: 19-33.

Smyth, J. and R. Hattam. 2005. 'Dropping out,' drifting off, being excluded: Becoming somebody without school. New York: Peter Lang.

Taylor, J. 2009. Stories of early school leaving: pointers for policy and practice. Fitzroy: Brotherhood of St Laurence.

Taylor, S. and P. Singh. 2005). The logic of equity practice in Queensland State Education - 2010. Journal of Education Policy 20, no. 6: 725-740.

Teese, R and J. Polesel. 2003. Undemocratic schooling: Equity and quality in mass secondary schooling in Australia. Melbourne: Melbourne University Press.

Te-Riele, K. 2006. Youth 'at risk': further marginalizing the marginalized? Journal of Education Policy 21, no. 2: 129-145.

Te-Riele, K. 2007. Educational alternatives for marginalized youth. The Australian Educational Researcher 34, no. 3: 53-68.

Thomson P. and L. Russell. 2007. Mapping the alternatives to permanent exclusion. York: Joseph Rowntree Foundation.

Thomson, P. and L. Russell. 2009. Data, data everywhere - but not all the numbers that count? Mapping alternative provisions for students excluded from school. International Journal of Inclusive Education 13, no. 4: 423-438.

White, R. and J. Wyn. 2008. Youth and society: exploring the social dynamics of youth experience $2^{\text {nd }}$ ed. South Melbourne: Oxford University Press. 
Table 1 Features of schools

\begin{tabular}{|c|c|c|c|c|c|}
\hline & $\begin{array}{l}\text { Woodlands Flexi } \\
\text { School } \\
\end{array}$ & $\begin{array}{l}\text { Victoria Meadows } \\
\text { Flexi School } \\
\end{array}$ & $\begin{array}{l}\text { Fernvale Education } \\
\text { Centre }\end{array}$ & $\begin{array}{l}\text { Cave Street Flexi } \\
\text { School }\end{array}$ & The Garage \\
\hline SPONSOR & $\begin{array}{l}\text { Campus of local } \\
\text { state school }\end{array}$ & $\begin{array}{l}\text { Church body in } \\
\text { partnership with a } \\
\text { Local Government } \\
\text { Authority }\end{array}$ & Church body & $\begin{array}{l}\text { Local youth service } \\
\text { with funding } \\
\text { support from nearby } \\
\text { high schools }\end{array}$ & $\begin{array}{l}\text { Charitable } \\
\text { institution }\end{array}$ \\
\hline STAFF & $\begin{array}{l}\text { Teachers: } 5 \\
\text { Admin: } 1 \\
\text { Work experience } \\
\text { coordinator: } 1 \\
\text { The school also } \\
\text { receives visits from } \\
\text { external staff such } \\
\text { as the Youth } \\
\text { Support Coordinator } \\
\text { and a youth worker } \\
\text { from a local youth } \\
\text { service. }\end{array}$ & $\begin{array}{l}\text { Teachers: FTE (full } \\
\text { time equivalent): } 4 \\
\text { Admin: FTE: } 1.5 \\
\text { School Officer - } \\
\text { Families Program: } \\
0.8 \\
\text { Community } \\
\text { Development } \\
\text { Officers: } 3 \\
\text { Volunteers - } \\
\text { families Program: } \\
1.2 \\
\text { Learning Program: } \\
0.5 \\
\text { Sessional Workers - } \\
\text { Music: } 0.8 \\
\text { Chaplin: } 0.8 \\
\text { Youth Support } \\
\text { Coordinator: } 0.3 \\
\text { Community Health } \\
\text { Nurse: } 0.2\end{array}$ & $\begin{array}{l}\text { Teachers: } 10 \\
\text { Youth } \\
\text { Workers/Teacher } \\
\text { Aides: } 12 \\
\text { Admin: } 4 \\
\text { Management: } 3.5 \\
\text { Kitchen/maintenance: } \\
3 \\
\text { Bus driver: } 1\end{array}$ & $\begin{array}{l}\text { Teacher: } 1 \\
\text { Youth Worker: } 1 \\
\text { Receives } \\
\text { administration } \\
\text { support from its } \\
\text { auspice agency. }\end{array}$ & $\begin{array}{l}\text { Teachers/Support } \\
\text { Staff: } 3 \\
\text { Admin: } 1\end{array}$ \\
\hline STUDENTS & 61 & $88(\mathrm{FTE}=47)$ & 107 & 21 & 18 \\
\hline AGES & $14-18$ & $15-21$ & $12-25$ & $14-16$ & $12-18$ \\
\hline $\begin{array}{l}\text { CO-ED or SINGLE } \\
\text { SEX }\end{array}$ & Co-ed & Co-ed & Single sex - female & Co-ed & Co-ed \\
\hline $\begin{array}{l}\text { CURRICULUM } \\
\text { OFFERINGS }\end{array}$ & $\begin{array}{l}\text { Year 10 } \\
\text {-Pre-vocational } \\
\text { Maths } \\
\text {-English } \\
\text { Communication } \\
\text {-Social \& } \\
\text { Community Studies } \\
\text {-Science \& } \\
\text { Technology } \\
\text {-Literacy } \\
\text {-Numeracy } \\
\text {-Personal } \\
\text { Development } \\
\text { Programs } \\
\text { Years 11 \& 12 } \\
\text {-Pre-vocational } \\
\text { Maths } \\
\text {-English } \\
\text {-Communication } \\
\text {-Social \& } \\
\text { Community Studies } \\
\text {-Creative Arts } \\
\text {-Information } \\
\text { Communication } \\
\text { Technology }\end{array}$ & $\begin{array}{l}\text { Years 10,11 \& } \mathbf{1 2} \\
\text {-Technology \& } \\
\text { Business } \\
\text {-Maths } \\
\text {-Creative Arts } \\
\text {-English } \\
\text { Communication } \\
\text {-Social \& } \\
\text { Community Studies } \\
\text {-Ethics } \\
\text {-Literacy } \\
\text {-Numeracy } \\
\text {-Certificate II in } \\
\text { Music Production } \\
\text {-Art \& Music } \\
\text {-Outdoor Recreation } \\
\text {-Cooking } \\
\text {-Life Skills } \\
\text {-Fitness } \\
\text { Health \& Nutrition }\end{array}$ & $\begin{array}{l}\text { Years 8-12 } \\
\text {-English } \\
\text {-Maths } \\
\text {-Science } \\
\text {-Study of Society \& } \\
\text {-Environment } \\
\text {-Visual Art } \\
\text {-Health \& Physical } \\
\text { Education } \\
\text { Years 11 \& 12 } \\
\text {-English } \\
\text { Communication or } \\
\text { Senior English } \\
\text {-Pre-vocational } \\
\text { Maths or Maths A } \\
\text {-Social \& } \\
\text { Community Studies } \\
\text {-Recreation } \\
\text {-Certificate I in } \\
\text { Hospitality } \\
\text { (Operations) } \\
\text {-Certificate II in: } \\
\text { Workplace Practices; } \\
\text { Visual Arts; } \\
\text { Contemporary Crafts; }\end{array}$ & $\begin{array}{l}\text {-Access } 10 \text { for those } \\
\text { students who want it } \\
\text { (i.e. most) - } \\
\text { provides connection } \\
\text { to Year } 10 \text { Level } \\
\text { Courses: } \\
\text {-English } \\
\text {-Maths } \\
\text {-Life Skills } \\
\text {-Social Skills }\end{array}$ & $\begin{array}{l}\text {-Certificate I in } \\
\text { Automative } \\
\text {-Access 10: } \\
\text {-Science } \\
\text {-English } \\
\text {-Maths }\end{array}$ \\
\hline
\end{tabular}




\begin{tabular}{|l|l|l|l|l|}
\hline & -Certificate II in & & and Business & \\
& Children's Services & & -Other Senior & \\
-Recreation Studies & & subjects can be & \\
-Literacy & accessed through the & & \\
& -Numeracy & Brisbane School of \\
& & Distance Education \\
and other training & & \\
institutions. & & \\
\hline
\end{tabular}

